\title{
Budaya Pandhalungan Sebagai Cultural Heritage Melalui Model Kreatif-Kritis Pembelajaran Sosiologi Kelas XII IPS SMAN 3 Jember
}

\author{
Aryni Ayu Widiyawati \\ SMA Negeri 3 Jember \\ J1. Basuki Rahmat No. 26 Jember \\ Email: aryniwidiyawati@yahoo.com
}

\begin{abstract}
Abstrak
Pembelajaran sosiologi menjadi penting bagi penanganan perubahanperubahan social yang terjadi dalam masyarakat. Soiologi yang lahir atas jawaban perubahan Industri di awal modernisasi Eropa, mempengaruhi segala aspek kehidupan manusia dari tradisionalitas menjadi modern. Perkembangan sosiologi di Indonesia tidak lepas dari peranan penjajahan Belanda. Ilmuwan Belanda seperti Van Leur, Souck $H$, dan lainnya tertarik mempelajari kondisi multicultural di Indonesia, dilanjutkan para ilmuwan pribumi. Sosiologi secara kontinyutas berperan besar sebagai ilmu dasar untuk melestarikan ketahanan budaya di berbagai daerah di Indonesia. Kondisi keragaman etnis merupakan peninggalan yang harus diwariskan melalui pembelajaran di sekolaha-sekolah menengah. Di daerah Jember, hibrida cultural antara budaya Jawa dan Madura merupakan peninggalan dari tradisi masyarakat migrasi. Dibuktikan dengan adanya budaya 'dhalung' menjadikan masyarakat Jember berbahasa Jawa dialek Jember, dan tradisi lainnya. Impelementasi kearifan local dengan mata pelajaran menarik perhatian penulis untuk mengkaji Budaya Pandhalungan sebagai Cultural Herritage dalam sosiologi. Hasil dari penelitian adalah meningkatnya pelestarian dan kelestarian dari Budaya Pandhalungan di kalangan siswa terutama di SMA Negeri 3 Jember dengan pembelajaran berbasis proyek yang terintegrasi dalam mata pembelajaran sosiologi dengan model pendekatan kreatif-kritis. Hal ini dapat menjadi potensi bagi kecintaan tanah air generasi muda, sehingga dapat berfokus pada kemajuan bangsa Indonesia.
\end{abstract}

Kata kunci : budaya, pandhalungan, pembelajaran berbasis proyek, sosiologi. 


\section{PENDAHULUAN}

Perputaran masa di era cibernetik menuntut manusia memiliki perfeksionitas atas segala hal. Berbaurnya nilai-nilai budaya, ekonomi, sosial, dan budaya di berbagai belahan dunia, menjadi bukti peradaban manusia tanpa sekat. Gerak sejarah tidak lagi menunjukkan tradisionalitas, atau bertumpu pada satu kerajaan. Juga tidak pula bergantung pada civitas diabolli dan civitas dei ${ }^{1}$. Kondisi dunia akhir-akhir ini menggambarkan sesuatu yang fluktuatif. Dalam laporan The National Commision on Teachers (1986:101), sesuatu di dunia sekarang dapat didefinisikan sebagai hasil ilmu pengetahuan dan artefak kemajuan manusia selama berabad-abad. Proses berlangsungnya revolusi teknologi sejak tahun 1980 mengubah pemikiran dunia dari penerima ilmu pengetahuan sentralistik menjadi pengolah ilmu pengetahuan yang divergen. Manusia tidak lagi tersekat oleh boundaries states (batas negara) untuk mengetahui segala sesuatu tentang dunia. Knowledge Society menyebutnya sebagai Globalisasi. Fenomena nyata abad postmodernis yang menggerakan manusia dan ilmu pengetahuan melintasi perbatasan internasional (Giddings, 1990). Peradaban global village merupakan hasil dari perpindahan modal, manusia, pelayanan, dan habitus yang membaur dalam globalisasi. Bukan hanya kemajuan pesat, globalisasi memberikan tantangan dan pengaruh tersendiri pada kehidupan manusia. Teknologi dan komunikasi turut andil menciptakan kehidupan manusia antara 'yang memiliki' dan 'tidak memiliki', menghasilkan masyarakat yang 'terbagi', siapa yang dapat menghadapi teknologi dan yang tidak ${ }^{2}$. Antara negara satu dengan lainnya memiliki sikap berbeda dalam menghadapi globalisasi. Hal ini sangat bergantung pada tingkat kemajuan pendidikan dan kualitas kebudayaan pada masyarakatnya.

Perkembangan globalisasi yang tumbuh pesat menjadi era cybernetik menuntut warga dunia untuk menjadi cerdas, berkarakter, dan bermoral. Pendidikan adalah kunci kemajuan bangsa yang dapat mewujudkan karakter cerdas warga dunia. Menurut Immanuel Kant, manusia tidak akan menjadi manusia sepenuhnya tanpa peran pendidikan, karena pendidikan adalah tentang memanusiakan manusia (human being). Proses pendidikan tidak akan pernah berlangsung lebih baik tanpa belajar dari masa lalu dan mendapat penjelasan dari realitas osial. Pembelajaran sosiologi di kelas merupakan proses dialektis yang menuntut aspek pedagogis, kognitif, relijius.

Pembangunan Kurikulum 2013 dan prinsip pemerintah menegakkan Gerakan Nasional Revolusi Mental, membutuhkan peran ganda guru dan siswa sebagai agen perubahan. Segala hal yang terjadi di era global, tidak hanya menuntut perpindahan modal, nilai, budaya, dan ekonomi, melainkan peradaban yang berakar kuat pada identitas kebangsaan. Dalam sosiologi, pembahasan mengenai gerak manusia dan peradaban manusia tidak terlepas dari campur tangan teori-teori budaya, sejarah, dan

1 Defnisi singkat tentang kedua civitas (negara) yang dikemukakan oleh Agustinus tersebut, Pertama Civitas Dei atau Negara Tuhan serta ada ilmuan filsafat yang mengartikannya sebagai Negara Tuhan, Negara Surgawi dan Negara Agama. Kedua, Civitas Terrena atau Diaboli, atau Negara Setan (Iblis), atau Negara Duniawi atau Negara Sakuler. Merujuk geitheiz sejarah yang masih berupa konsep polis (negara-kota) Romawi yang wilayahnya masih sempit.

2 Flinders University, "Effect of Globalization on Education and Culture, 2010, berisi tentang perkembangan science yang memiliki dua efek, satu membanggakan sedang lainnya mengubah tatanan manusia menjadi brutal, pragmatis, dan mengekslusifkan diri. 
pendidikan. Mengingat kebudayaan merupakan cara manusia untuk mempertahankan eksistensinya, maka dibutuhkan sebuah ilmu untuk menjelaskan realitas-realitas social yang telah ada dari masa lampau, kini, dan prediksi masa depan. Sosiologi tidak hanya eksplanasi dari sejarah Revolusi Industri di Eropa, juga menjadi kunci bagi perkembangan manusia yang etnografisnya terdiri dari beragam etnis (multicultural).

Era transisi perubahan sosial dalam perkembangan masyarakat Indonesia yang multikultural menimbulkan konsekuensi logis yang unpredictable. Antara lain merebaknya keraguan akan nilai dan tatanan normatif yang telah mapan, mengalami erosi jika tidak dilakukan penguatan orientasi. Bantuan ilmu sosiologi dengan segala komponen konsepsionalnya mendapat sambutan positif dari kalangan praktisi pendidikan, sebagai wujud alternatif untuk memperkuat ketahanan sosial melalui pendidikan. Pendidikan merupakan alat untuk mengembangkan kesadaran diri sendiri dan kesadaran sosial menjadi suatu paduan yang stabil sehingga pendidikan tidak dapat dipisahkan dari kehidupan sosial. Pendidikan sangat dibutuhkan oleh masyarakat. Oleh karena itu, pendidikan bersifat fungsional dalam sistem kehidupan manusia. Aktivitas masyarakat dalam pendidikan merupakan sebuah proses sehingga pendidikan dapat dijadikan instrument oleh individu untuk dapat berintraksi secara tepat di komunitas dan masyarakatnya. Pada sisi yang lain, pembelajaran sosiologi dalam pendidikan pendidikan akan memberikan eksplanasi relevan dengan kondisi kekinian masyarakat, sehingga setiap individu sebagai anggota masyarakat dapat beradaptasi dengan pertumbuhan dan perkembangan berbagai fenomena yang muncul dalam masyarakatnya (Batubara, 2004: 13-14).

Namun demikian, pertumbuhan dan perkembangan masyarakat merupakan bentuk lain dari pola budaya yang dibentuk oleh suatu masyarakat. Pendidikan tugasnya tentu saja memberi penjelasan mengapa suatu fenomena terjadi, apakah fenomena tersebut merupakan sesuatu yang harus terjadi, dan bagaimana mengatasi segala implikasi yang bersifat buruk dari berkembangnya fenomena tersebut, sekaligus memelihara implikasi dari berbagai fenomena yang ada. Kajian sosiologi dalam pembelajaran menekankan implikasi dan akibat sosial dari pendidikan dan memandang masalah-masalah pendidikan dari sudut totalitas lingkup sosial kebudayaan, politik dan ekonomisnya bagi masyarakat.

Pembelajaran Sosiologi yang kreatif dan kritis memandang gejala pendidikan sebagai bagian dari struktur sosial masyarakat (Khaldun, 2008: 73). Lembaga-lembaga, kelompok sosial dan proses sosial terdapat hubungan yang saling terjalin, di dalam interaksi sosial itu individu memperoleh dan mengorganisasikan pengalamannya. Penjelasan tersebut melekat kuat aspek sosiologisnya. Sementara dari segi pedagogisnya, bahwa seluruh individu dan masyarakat dari anak-anak sampai orang dewasa, kelompok-kelompok sosial dan proses-proses sosialnya, berlangsung di seputar sistem pendidikan yang selalu bergerak dinamis. Tidak dapat dipungkiri bahwa beberapa grand theory yang terukir dalam sejarah menjadi paradigma yang mempengaruhi dunia pendidikan. Paradigma besar dalam sosiologi kemudian berkembang menjadi tiga, yaitu: Pertama, struktural, fungsional dan interaksionisme. Para pendidik sadar atau tidak menganut salah satu paradigma sosiologi yang secara kontinyuitas berperan dalam pertahanan identitas kebangsaan dan ketahanan budaya. 
Suatu kenyataan yang tidak dapat dipungkiri banyak negara di dunia ini yang menempatkan pembelajaran sosiologi sebagai unsur penting dalam pendidikan kebangsaan negara. Anthony D. Smith $(1991)^{3}$ mengungkapkan sosiologi yang tana nilai membantu masyrakat Eropa era Industri yang mengalami degradasi rasa kecintaan tanah air mempergunakan realitas teori sosiologi untuk membuat kebangsaan sebagai formasi identitas kebangsaan. Peradaban terbangun karena adanya fenomena kebersamaan kolektif suatu masyarakat. Hal ini diyakini oleh Anthony Giddens bahwa materi sosiologi dalam hal ketahanan kebudayaan mampu mengembangkan sifat dan karakter generasi bangsa yang intelektual, relijius, dan berbudaya. Ketika generasi muda menjadi pemegang peran utama dan pendukung dalam menjalankan kehidupan bangsa, maka karakter yang sudah terbentuk menjadi landasan kuat dalam melaksanakan peran tersebut. Hal itu terjadi karena melalui pembelajaran sosiologi, masyarakat memahami bagaimana bangsa berkembang dan bagaimana menghadapi ketidakpastian dalam perubahan. Pengajaran Sosiologi di Sekolah Menengah Umum berfungsi untuk meningkatkan kemampuan berfikir, berperilaku, dan berinteraksi dalam keragaman realitas sosial dan budaya berdasarkan etika. Permasalahan yang dihadapi dalam kehidupan bangsa dan bagaimana masyarakat belajar dari pengalaman pola perubahan masyarakat akan membentuk membentuk masa depan yang lebih baik berdasarkan sifat dan karakter utama bangsa. Oleh karena itu, pembelajaran sosiologi memiliki fungsi strategis dalam mengembangkan jiwa dan karakter bangsa dan membangun kehidupan masa depan yang lebih baik. Jiwa dan karakter tersebut dijalin dan didasarkan kepada karakter diri orang perseorangan peserta didik yang tercermin dalam visi kehidupan, sikap hidup, nilai dan kehidupan, kemampuan mengembangkan kehidupan sosial, ekonomi, budaya, agama serta pelestarian terhadap budaya-budaya lokal. Pelestarian terhadap budaya-budaya lokal merupakan bagian dari warisan (Ahimsa : 1990) ${ }^{4}$ yang dapat diterapkan dalam pengembangan pembelajaran sosiologi, yang akan mendukung ketercapaian karakter kebangsaan negara. Salah satunya adalah budaya Pandhalungan yang ada di Kabupaten Jember.

Budaya lokal yang dikembangkan, berdasarkan teori globalokal merupakan friksi dari globalisasi. Salah satu kajian yang jarang sekali diteliti oleh para sejarawan, antropolog, maupun budayawan adalah budaya Pandhalungan. Budaya ini tetap ada hingga hari ini, namun jarang sekali mendapat perhatian masyarakat umum. Karena selama ini, kajian mengenai sejarah lebih cenderung berfokus pada sejarah politik, dan konflik kedaerahan. Maka, perlu untuk diteliti mengenai sejarah lokal dalam konteks teori perubahan social dan structural fungsional sosiologi untuk memperkuat identitas kebangsaan yang multietnik.

Penelitian tentang korelasi pembelajaran sosiologi yang konstruktivis, budaya, serta penerapan dalam model kreatif dan kritis sesuai tujuan pendidikan nasional dalam

\footnotetext{
${ }^{3}$ Anthony D. Smith dalam "National Identity" yang menyebut Revolusi Industri sebagai Satanic Mills, yakni pabrik setan karena mengakibatkan perubahan social luar biasa bagi masyarakat Eropa. Degradasi moral terjadi dimana-mana, dan identitas kebangsaan menjadi taruhannya. Karl Marx, Smith, Durkheim beramai-ramai menentang system kapitalisme dengan memunculkan ilmu sosiologi di Eropa.

${ }^{4}$ Prof. Heddy Ahimsa, dosen luar biasa UGM dalam artikelnya berjudul "Herritage, Warisan atau Pusaka" menjelaskan sedemikian detail mengenai kepemilikan warisan, sebagai hasil eksistensialisme keberadaan manusia.
} 
beberapa hal telah dikaji secara komperehensif oleh para peneliti. Untuk melakukan pemahaman dasar mengenai budaya Pandhalungan, pustaka yang dapat menjadi referensi adalah artikel ilmiah karya Christanto P. Raharjo yang disampaikan dalam Jelajah Budaya di Yogyakarta pada tahun 2006 yang berjudul "Sebuah Periuk Besar dalam Masyarakat Multikultural”. Artikel ilmiah ini menuliskan tentang sebuah awal Pandhalungan yang tercipta dari kondisi sosio-kultural masyarakat Jember yang mengalami keterpaduan dari etnis mayoritas Jawa dan Madura. Dalam konsep simbolik, budaya ini digambarkan sebagai 'periuk besar' yang menjadi tempat bertemunya bermacam masyarakat berbeda etnis dan kebudayaan, kemudian saling berinteraksi dalam ruang dan waktu sehingga melahirkan varian baru kebudayaan yang disebut Pandhalungan. Berikutnya karya Drs. Edy Burhan Arifin berjudul "Pertumbuhan Kota jember dan Munculnya Budaya Pandhalungan" yang disampaikan dalam konferensi nasional Sejarah VIII di Jakarta tahun 2006. Artikel ini berisikan tentang awal terbentuknya masyarakat Jember yang sejak pertengahan abad ke XIX sampai awal abad XX, terjadi migrasi besar-besaran sejak salah satu pengusaha Belanda bernama George Birnie yang pada tanggal 21 oktober 1859 bersama Mr. C. Sandenburg Mathiesen dan van Gennep mendirikan NV Landbouw Maatsccapij Oud Djember (NV. LMOD) yang bergerak di bidang perkebunan. Belanda mendatangkan pekerja-pekerja dari etnis Madura, Cina, Arab, dan juga orang Belanda. Lambat laun Jember berubah statusnya dari bagian afdelling Bondowoso menjadi afdeling Jember. Terjadi perpaduan budaya diantara etnis-etnis tersebut sehingga terbentuklah budaya Pandhalungan sebagai hasil dari akulturasi etnis mayoritas Jawa dan madura.

Berkembangnya Budaya Pandhalungan dapat dilihat dari tulisan Prof. Ayu Sutarto berjudul "Sekilas tentang Masyarakat Pandhalungan" yang membahas tentang perkembangan masyarakat Jember dalam konteks geopolitik dan geo-sosio-kultural yang menjadi bagian dari masyarakat tapal kuda yakni masyarakat yang bertempat tinggal di suatu kawasan di provinsi Jawa Timur yang membentuk lekukan mirip ladam/kasut besi kaki kuda. Kawasan ini memiliki karakteristik tertentu yang didominasi oleh pendukung islam kultural dan abangan. Pendukung islam kultural dimotori oleh para kiai dan ulama, sementara kaum abangan dimotori oleh tokoh-tokoh politik dan tokoh-tokoh yang tergabung dalam aliran kepercayaan. Budaya Pandhalungan menurut pandangan prof. Ayu Sutarto merupakan budaya baru yang terbentuk akibat akulturasi antara mayoritas etnis madura dan etnis Jawa. Menurutnya, kajian mengenai budaya Pandhalungan memang sangat terbatas sumbernya baik dari dokumen maupun buku-buku, sehingga perlu penelitian lebih lanjut mengenai pendalaman budyaa Pandhalungan yang ada di kota Jember. Budaya modernisasi yang kian berkembang juga dapat diminimalisir dengan adanya konsep globalokal, yakni berpedoman pada budaya lokal masyarakat. Buku yang mengkaji tentang klasifikasi berbagai budaya di Jawa Timur, diantaranya: makanan khas rakyat, tari-tarian tradisional, bahasa rakyat, peribahasa, minuman tradisional, dan lain-lain adalah buku karya Prof. Ayu Sutarto, dkk berjudul "Upacara Adat Jawa Timur Jilid III". Budaya Pandhalungan ditulis dalam buku tersebut karena menjadi bagian dari budaya Jawa Timur. Selain itu, adapun referensi untuk memperkuat keberadaan budaya Pandhalungan di Jember, yakni karya Mikka Wildha berjudul "Budaya Pendhalungan 
dalam Masyarakat Multikultural di Wilayah Tapal Kuda, Jawa Timur”. Berisi tentang pengamatan terhadap budaya Pandhalungan mencakup tari-tarian tradisional, seni pertunjukkan, dan seni bela diri yang berkembang di daerah Jember, Bondowoso, dan Lumajang. Selain itu, karakteristik masyarakat wilayah tapal kuda juga dituliskan yang memiliki watak keras, pekerja, dan ekspresif untuk orang-orang madura, diimbangi dengan sikap cenderung mengalah bagi orang-orang Jawa. Semuanya berakulturasi membentuk dan mengembangkan budaya Pandhalungan. Sehingga karya-karya tersebut dapat menjadi salah satu referensi mengenai perkembangan budaya Pandhalungan dalam era kekinian. Pengkajian teori-teori yang digunakan untuk meneliti perkembangan budaya Pandhalungan dapat dikaitkan dengan pendekatan multikulturalisme/multietnik, dan teori salad bowl. Maka, perlu dikaji buku karangan berjudul “American Salad Bowl”, diantaranya menjelaskan tentang metode penelitian masyarakat multikulturalisme dalam soiologi, bagaimana menyelidiki jenis-jenis kebudayaan di dunia dengan salad bowl, yakni teori yang menjelaskan bahwa kebudayaan global yang baru-baru ini muncul di masyarakat melebur jadi satu kesatuan (global culture), namun tetap dengan tanpa meninggalkan karakter budaya asli.

Selain itu, pembelajaran sosiologi yang kreatif dan kritis dapat dilihat pada kajian Michael Foucault dalam bukunya "Education in Sociology: Knowledge, Power, and Critical" yang menganalisis sosiologi sebagai pembelajaran konstruktivis untuk mempersiapkan generasi dalam tantangan abad - 21. Pendidikan konvensional dianggap terlalu mengontrol kreativitas dan kritikal siswa menangani berbagai permasalahan di abad pengetahuan. Kebudayaan dan ilmu pengetahuan selalu berjalan sejajar dalam tataran pendidikan. Sehingga pembelajaran sosiologi dalam tataran budaya Pandhalungan merupakan pengalaman nyata yang terorganisir dalam masyarakat Jember kemudian terbentuklah tingkah laku di kalangan peserta didik, dan sekolah dianggap sebagai bagian dari lingkungan totalitas kebudayaan itu. Maka pembelajaran sosiologi dalam konteks model pembelajaran kreatif-kritis memperbincangkan dan berusaha untuk menemukan bagaimana memanipulasi proses pendidikan untuk mengembangkan kepribadian yang lebih baik. Perkembangan penelitian soiologi akhirakhir ini membuktikan bahwa budaya Pandhalungan menjadi 'diskursus spesifik' yang harus diteliti. Budaya Pandhalungan sebagai bagian dari kebudayaan jember, dapat dicermati keberadaannya yang mengalami perubahan sosial di kehidupan sehari-hari masyarakat Jember. Dalam pembelajaran sosiologi, budaya Pandhalungan termasuk dalam perubahan social dan fungsionalisme struktural yang dapat dikembangkan dalam pengembangan proyek di sekolah sebagai bentuk dari pewarisan budaya. Oleh karena itu, penulis tertarik untuk meneliti penelitian tindakan kelas tentang Budaya Pandhalungan Sebagai Cultural Heritage Melalui Model Kretif-Kritis Pembelajaran Sosiologi Kelas XII IPS di SMAN 3 JEMBER.

Tujuan dan manfaat penelitian adalah untuk mendeskripsikan tentang peran besar budaya lokal bagi pembelajaran sosiologi dalam pengajaran kreatis-kritis sebagai pusaka atau warisan budaya masyarakat Jember untuk memperkuat karakter kebangsaan siswa melalui konstruktivitas, serta bermanfaat sebagai referensi bagi penelitianpenelitian selanjutnya. 


\section{METODE PENELITIAN}

Dalam penelitian tindakan (action research) ini peneliti terjun langsung dalam kegiatan proses pembelajaran sesuai dengan skenario tindakan yang ditetapkan melalui siklus tindakan dan peneliti melibatkan diri selama proses pembelajaran serta diikuti secara terus menerus.Tempat penelitian dilaksanakan di SMA Negeri 3 Jember kelas XII IPS, baik berlangsung di dalam kelas maupun di luar kelas sesuai dengan penugasan untuk pemecahan masalah yang relevan dengan kehidupan masyarakat. Waktu penelitian dilaksanakan selama sebulan sejak awal Agustus 2017. Teknik pengumpulan data yang digunakan dalam penelitian tindakan ini adalah dengan menggunakan teknik dokumentasi, kuisioner, wawancara, dan observasi partisipatoris. Pengolahan data dilakukan secara sistematis untuk disajikan sebagai hasil penelitian. Proses pemilihan data lebih difokuskan pada data yang dianggap dapat memberikan arahan untuk pemecahan masalah dan tujuan penelitian. Data yang memenuhi persyaratan selanjutnya disajikan secara sistematis agar lebih mudah untuk dipahami keterkaitan hubungan antara bagian-bagian secara utuh tidak terlepas dari yang lainnya. Untuk memperoleh keabsahan data digunakan proses validasi data melalui teknik triangulasi. Teknik triangulasi dimaksudkan untuk memperoleh derajad kepercayaan yang tinggi. Sedangkan untuk memperoleh tingkat signifikansi dalam model statistik digunakan uji hipotesis dengan menggunakan tingkat kepercayaan sebesar $90 \%$ atau alpha 10\%. Penggunaan alpha $10 \%$ atau tingkat kepercayaan 90\% dengan pertimbangan bahwa data yang akan dianalisis merupakan obyek sosial.

Adapun langkah-langkah atau prosedur dalam penelitian tindakan kelas dalam model pembelajaran kreatif-kritis adalah sebagai berikut: (1)Penetapan Siklus. Penelitian ini menggunakan dua siklus (siklus I dan siklus II). Siklus pertama, terdiri dari dua tahap dengan tiga tindakan. Siklus Kedua terdiri satu tahap dan satu tindakan yaitu tahap ketiga implementasi model pembelajaran kreatif-kritis yang efektif dengan satu tindakan (tindakan IV). Dalam diskusi digunakan kelompok kecil untuk membahas materi Perubahan Sosial dnegan subjek Budaya Pandhalungan dan Pewarisannya (Cultural Heritage) sebagai kasus penugasan yang dilanjutkan dengan tutorial untuk menyelesaikan tugas serta latihan mandiri. Jumlah kelompok ada 4 kelompok dan masing-masing kelompok terdiri dari 8-12 orang siswa kelas XII IPS. (2) Perencanaan Tindakan. Perencanaan tindakan terdiri dari a) persiapan modul dan bahan ajar sesuai dengan silabus yang telah disusun, b) penyediaan alat dan media pembelajaran dan c) persiapan tindakan. (3) Pelaksanaan Tindakan Pembelajaran. Pelaksanaan tindakan pembelajaran dalam kedua siklus tersebut adalah sebagai berikut: (a) Siklus Pertama dengan Tindakan I yaitu untuk mendiagnosis siswa. Tindakan II yang dilaksanakan selama tiga kali pertemuan bertujuan agar mahasiswa dapat mempelajari materi pokok bahasan secara cepat dan mengingat lebih banyak, serta mampu mengidentifikasikan sekaligus membuat alternatif pemecahannya baik secara konseptual maupun dengan melihat kondisi riil di lapangan. Tindakan III yang dilaksanakan selama empat kali pertemuan bertujuan agar siswa memiliki kemampuan untuk dapat membuat perencanaan dan pembuatan keputusan yang rasional yang berkaitan dengan permasalahan sosiologi pendidikan dan kehidupan sosial kemasyarakatan. (b) Siklus Kedua terdiri satu tahap dan satu tindakan yaitu implementasi model pembelajaran 
kreatif-kritis yang efektif dengan satu tindakan (tindakan IV). Tindakan IV yang dilaksanakan selama lima kali pertemuan ini bertujuan agar mahasiswa memiliki kemampuan analitis dalam memahami seluk beluk sosial kemasyaraktan (sosial studies) dan permasalahannya secara komprehensif sehingga di dalam membuat keputusan rasional sudah mempertimbangkan faktor resiko baik dari aspek sosial budaya maupun ekonomi, politik dan keamanan kemasyarakatan. (4) Pemantauan dan Evaluasi. Pengamatan tindakan atau pemantauan dilakukan pada waktu proses tindakan berlangsung. Sehubungan dengan pelaksanaan tindakan pembelajaran yang telah disebutkan di muka, maka semua hasil pengamatan dicatat dalam lembar penilaian. Evaluasi dilakukan untuk menilai respon dari setiap rancangan tindakan sesuai dengan pokok bahasan yang ingin dicapai dalam pembelajaran. Skala penilaian mengacu pada pembelajaran karakter Kurikulum 2013 menyangkut: penghargaan, toleransi, kritis, aktif, kreatif. Dengan hasil evaluasi ini digunakan sebagai dasar untuk melakukan refleksi selanjutnya. (5) Refleksi. Kegiatan refleksi dilakukan untuk melakukan analisis dan memaknai hasil tindakan. Atas dasar analisis nilai kebermaknaan hasil tindakan untuk selanjutnya ditarik suatu kesimpulan apakah perlu merevisi kegiatan tindakan dengan melakukan intervensi bentuk gagasan baru atau hanya sekedar penyempurnaan langkah-langkah kegiatan yang dilakukan sebelumnya. (6) Keberhasilan Tindakan (Peningkatan kualitas hasil belajar). Untuk menentukan keberhasilan tindakan digunakan dua pendekatan yaitu pendekatan indikator peningkatan hasil dan pendekatan normatif penilaian hasil belajar. Langkah terakhir dalam pelaksanaan penelitian adalah analisa data yang digunakan dalam penelitian tindakan ini adalah dilakukan dengan deskriptif kualitatif dari hasil refleksi dan evaluatif. Sedangkan untuk menguji tentang dampak model pembelajaran kreatif-kritis terhadap peningkatan kualitas hasil belajar digunakan dengan analisis statistik non-parametrik dan statistik sederhana. ${ }^{5}$

\section{HASIL DAN PEMBAHASAN}

\section{Budaya Pandhalungan Sebagai Cultural Heritage Jember}

Budaya Pandhalungan secara historis (kesejarahan) berawal dari migrasi besarbesaran yang dilakukan etnis Cina, Jawa, Madura, Arab, dan Belanda ke daerah Jember. Orang-orang Jawa dan Madura terutama bekerja sebagai pedagang, petani, pegawai, dan pendidik. Secara historis, perpindahan penduduk dari berbagai etnik membuat penduduk Jember menjadi heterogen yang terus berkembang bersamaan dengan pertumbuhan wilayahnya. Budaya Pandhalungan menjadi cerminan multikulturalisme bangsa yang tercermin dalam setiap polesan dan keunikan budaya di tiap daerah di wilayah kesatuan NKRI. Kekayaan budaya Pandhalungan sebagai budaya campur, menghasilkan berbagai unsur-unsur budaya diantaranya: bahasa lokal, perpaduan tari-tarian, makanan minuman khas lokal, yang menjadi bagian dari identitas kebangsaan. Bertemunya berbagai suku bangsa di kota Jember, menyebabkan munculnya sebuah budyaa yang relatif unik. Tradisi dan identitas berhubungan secara dialektis. Setiap kultur membawa dan berusaha mempertahankan tradisinya masing-masing. Demikian pula dengan

\footnotetext{
${ }^{5}$ Terdapat dalam buku Poh Swee Hiang. (2000). Kemahiran Berfikir Secara Kritis dan Kreatif terbitan Kuala Lumpur. Berisikan tentang pengembangan analisis sederhana dari penggunaan model belajar berpikir Kritis-Kreatif yang dapat membantu pengajar meningkatkan prestasi belajar siswa
} 
masyarakat Madura dan masyarakat Jawa yang berada di jember. Untuk melestarikan kultur yang mereka miliki, biasanya masing-masing komunitas berusaha mensosialisasikan kultur tersebut kepada komunitasnya, sehingga akan memperkokoh konstruksi identitas kultural pada lokalitas masing-masing.

Di kalangan orang Jawa, karakteristik yang paling dibutuhkan untuk melakukan komunikasi adalah keajegan masyarakat, sopan santun, dan cenderung memiliki strata dalam berbahasa. Kultur Jawa mengajarkan hidup harmoni, rukun, dan mampu mengatasi berbagai perbedaan. Di mata orang jawa menjadi "Jawa" berarti harus menjadi manusia yang beradab, memahami bagaimana seharusnya bertingkah laku yang baik. Hidup yang benar adalah hidup sebagai orang Jawa, memperlihatkan tingkah laku halus, berkata-kata yang pantas dan mempertahankan tatanan yang benar. Pada masyarakat Madura, mereka cenderung mempertahankan pola tinggal berkelompok, dalam pola "taneyan lanjeng" (Yuswadi, 2006). Karakteristik orang madura cenderung ekspresif, bersuara keras, sangat relijius, dan keras, pekerja keras. Adapun slogan yang dimiliki orang Madura dalam bukunya Latief ${ }^{6}$, “....reng tak islam, tak madura”, orang yang bukan islam berarti bukan orang madura. Dalam kehidupan sehari-hari, dua etnis mayoritas tersebut saling melakukan komunikasi budaya dengan budaya minoritas lain seperti: cina, arab, dan mandar. Hasilnya, meskipun bahasa yang dimiliki berbeda, namun tetap menggunakan bahasa daerah sama dialek Jember.

Etnis mayoritas yang paling mendominasi adalah etnis Jawa dan Madura. Keduanya menjadi ikon keberagaman budaya di wilayah Jember. Apabila sedang mengunjungi daerah Jember, terutama di toko-toko Cina atau Arab di sepanjang jalan raya sultan agung, akan sangat terlihat kekentalan bahasa yang diucapkan. Etnis Arab dan Cina meski memiliki bahasa asli yang berbeda, namun bahasa sehari-hari mereka adalah bahasa Jawa dialek Jember, dan bahasa Madura dialek Madura. Keunikann linguistik ini juga dipakai oleh penduduk Jember yang sudah terkontaminasi dengan budaya campuran, mereka cenderung berbicara dengan bahasa campuran. Terkadang memakai bahasa Indonesia logat Madura atau bahasa Jawa logat Madura. Di daerah Jember bagian utara yakni: Arjasa, Jelbuk, Kalisat, dan lainnya cenderung memakai bahasa Madura dialek Jember, berbeda hal dengan Jember bagian selatan yakni: Ambulu, Puger, Mayang, Jatiroto, dan lainnya justru memakai bahasa Jawa logat Jawa, atau bahasa Jawa dialek Jember. Kedua kelompok masyarakat yang mayoritas dan dominan menjadi hal penting dalam proses interaksi dialogis makna, pesan-pesan yang dipertukarkan, diapdukan, atau saling dipertukarkan posisinya, antara subjek dan objek komunikasi secara timbal balik. Friedman menyebutkan inilah yang nantinya bertahan dalam gaya hidup masing-masing etnis atau disebut hibridisasi (Pieterse, 1995:46) ${ }^{7}$. Penduduk Jember yang masing-masing membawa identitas kultur daerahnya, akan membangun mekanisme untuk saling menonjolkan kultur spesifiknya. Latar belakang sama sebagai perantau dan perantau baru, menghasilkan suatu bentuk kompromi budaya yang dikenal sebagai "hibridisasi budaya". Interaksi yang dominan ini tidak disertai

\footnotetext{
${ }^{6}$ Dalam Budaya Carok Madura terbitan Universitas Jember tahun 2007

${ }^{7}$ Nederveen pieterse dalam Globalization as Hibridization, yakni intrepretasi terbaik dari globalisasi adalah ide mengenai dunia yang terstandar dan berseragam, dilengkapi dengan ekonomi yang semakin komersial dan ambigu. Globalisasi adalah hibridisasi yang sangat absurd.
} 
dengan egoisme kultural masing-masing etnis, melainkan terjadi persilangan budaya sehingga disebutlah sebagai Budaya Pandhalungan. Seperti yang telah diungkapkan dalam teori "salad bowl", bahwa masing-masing budaya daerah berinteraksi dengan budaya lain tanpa menenggelamkan budaya asli dan menghasilkan budaya baru. Individu-individu dari masing-masing etnis ini akan mengembangkan keberagaman identitas sosial yang diistilahkan dengan bestowers of identity (Baumman dalam Yuswadi, 2006). Identitas lokal yang dikembangkan oleh komunitas-komunitas iniakan memperkuat identitas kebangsaan yang dimiliki bangsa Indonesia. Pandhalungan dalam konteks masyarakat multikultural menghasilkan sebuah budaya baru, di wilayah kebudayaan ini juga bisa dilihat adanya budaya masing-masing etnis yang tetap dipertahankan dalam sebuah proses sosial yang menempati ruang dan waktu yang sama. Meskipun dalam kehidupan sehari-hari mereka berinteraksi, tetapi mereka tetap kukuh dalam menjalankan aktivitas budaya sesuai dengan identitas masing-masing demi terjaganya jati diri dan, meminjam istilah Barker, absolutisme etnis. Hal itu membuktikan tesis yang dilontarkan Pietersen bahwa meskipun terjadi proses hibridasi ketika berada dalam ranah interaksi sosial, tetapi identitas etnis tidak terhapus begitu saja dalam tataran kognitif dan praktis kehidupan masyarakat Jember.

Dilihat dari perilakunya sehari-hari, orang Pandhalungan sangat akomodatif dan menghargai perbedaan. Etika sosial mencakup tata krama, sopan santun, atau budi pekerti orang Pandhalungan berakar pada nilai-nilai yang diusung dari budaya Jawa dan Madura. Dalam perkembangan selanjutnya, budaya orang Pendhalungan di Jember sarat dengan nuansa islami. Sebabnya, ulama dan kiai bukan hanya menjadi tokoh panutan, melainkan juga berkuasa secara politis. Secara garis besar, ciri-ciri masyarakat pandhalungan yakni: (1) sebagian besar agraris tradisional, berada di pertengahan jalan antara masyarakat tradisional dan masyarakat industru, tradisi dan mitos memiliki tempat dominan dalam kesehariannya, (2) sebagian besar masih didominasi oleh tradisi lisan tahap pertama (primary orality) dengan ciri-ciri suka mengobrol, ngrasani, takut menyimpang dari pikiran dan pendapat yang berlaku umum, (3)terbuka terhadap perubahan, (4)ekspresif, transparan, tidak suka memendam perasaan atau berbasa-basi, (5) Paternalistik, keputusan diambil berdasarkan tokoh panutan masyarakat.

Di wilayah Jember, kondisi tersebut sangat tampak pada aktivitas budaya di wilayah selatan dan utara. Sebagai produk segregasi etnis ala kolonial, masyarakat etnis Jawa yang menempati wilayah selatan Jember (seperti Ambulu, Wuluhan, Balung, Puger, Gumukmas, Kencong, Jombang, Umbulsari, dan Semboro) sampai saat ini masih mempraktekkan produk budaya Jawa baik dalam hal bahasa, kesenian, maupun adatistiadat lainnya. Masyarakat Jawa di Ambulu dan Wuluhan, misalnya, sampai saat ini masih melestarikan kesenian Reog yang berasal dari nenek moyangnya di Ponorogo. Di samping itu, hampir semua masyarakat di selatan juga menggemari Wayang Kulit, Jaranan, dan Campursari. Sedangkan untuk urusan pendidikan mereka tetap berorientasi pada pendidikan formal, meskipun di sana juga terdapat pondok pesantren. Di wilayah utara, masyarakat tetap bertahan pada orientasi budaya Madura. Bahasa Madura merupakan bahasa sehari-hari masyarakat di Kecamatan Arjasa, Jelbug, Sukowono, Kalisat, Sumberjambe, Ledokombo, Mayang, dan sebagian Pakusari. Di samping ludruk ala Madura, masyarakat di sana gemar melihat pertunjukan Hadrah sebagai kesenian 
pesantren yang menjadi orientasi pendidikan etnis Madura. Pengajian juga menjadi acara favorit karena di samping mendapatkan wejangan-wejangan tentang Islam, mereka juga bisa bertemu dengan para Lorah (sebutan untuk kyai) ataupun Gus (anak kyai) yang dianggap bisa mendatangkan berkah bagi kehidupan warga. Sedangkan di wilayah tengah kota dan pinggiran kota di samping berdagang, etnis Tionghoa sebagai berkah reformasi politik nasional juga mulai mengembangkan kesenian Barongsai dan Liang liong sebagai kesenian khas mereka. Pada peringatan Imlek, kesenian ini dipertontonkan menyusuri jalan-jalan protokol kota Jember. Meskipun generasi mudanya sudah banyak yang menggunakan Bahasa Indonesia dan Bahasa Jawa dengan aksen Tionghoa, Bahasa Mandarin sudah mulai diperkenalkan lagi. Dalam hal pendidikan sebagian besar warga etnis Tionghoa tetap menyekolahkan anak-anaknya ke sekolah-sekolah yang dikelola gereja, seperti SD, SMP, dan SMA Santo Yusuf, SMA Setya Cadika, dan lain-lain. Sementara etnis Arab tetap kukuh mempertahankan identitasnya dengan tetap melestarikan pernikahan sesama etnis. Mereka juga masih mempertahankan Musik Gambus sebagai pemenuh kebutuhan estetiknya. Kesenian yang berkembang di wilayah pandalungan bernuansa agraris dan keagamaan (Islam). Menurut Ferdinand Tonnies disebut sebagai gesselschaft (masyarakat paguyuban) yang terbentuk di masyarakat Jember daerah pedesaan memiliki karakteristik gotong royong, kekeluargaan, relijius, nonn-ecnomic people (tidak perhitungan), sebaliknya dalam masyarakat Jember perkotaan membentuk semacam gemeinschaft (masyarakat patembayan) yang bersifat individualistik, utalitarian (kepentingan), dan praktis. Inilah perkembangan budaya Pandhalungan sebagai warisan karakteristik masyarakat Jember berdasarkan perspektif sosiologis.

\section{Budaya Pandhalungan dalam Pembelajaran Sosiologi Model Kreatif- Kritis}

Penilaian Hasil Tindakan Siklus I

Berdasarkan pelaksanaan tindakan pada siklus I diperoleh hasil penilaian siswa sebagai berikut:

Tabel IV-1: Hasil Penilaian Siklus I

\begin{tabular}{|cc|c|c|}
\hline $\begin{array}{l}\text { Rentang } \\
\text { nilai }\end{array}$ & Frekuensi & $\begin{array}{l}\text { Prosentase } \\
(\boldsymbol{\%})\end{array}$ \\
\hline $85-100$ & (A) & 0 & 0 \\
\hline $80-<85$ & $(\mathrm{~A}-)$ & 3 & 6,82 \\
\hline $76-<80$ & $(\mathrm{~B}+)$ & 8 & 18,18 \\
\hline $70-<76$ & (B) & 11 & 25,00 \\
\hline
\end{tabular}

Hasil penelitian menunjukkan bahwa respon siswa terhadap pembelajaran kreatif-kritis cenderung lebih positif dibandingkan menggunakan pembelajaran konvensional. Respon asiswa lebih baik ketika pembelajaran tidak lagi menggunakan pendekatan konvensional, di mana mahasiswa menerima informasi tidak mendapatkan sendiri informasi tersebut. Proses pembelajaran berlangsung lebih menyenangkan dengan model pembelajaran kreatif-kritis. Pada gilirannya, pembelajaran yang 
menyenangkan dapat membawa dampak peningkatan prestasi belajar siswa. Prestasi belajar yang diketahui dari nilai rerata siswa kelas XII IPS di SMAN 3 Jember menunjukkan bahwa nilai rata-rata yang diperoleh siswa dengan model pembelajaran kreatif-kritis menunjukkan lebih baik dibandingkan dengan model pembelajaran secara konvensional sebelum menggunakan model pembelajaran kreatif-kritis. Di samping dari aspek penilaian hasil belajar, ternyata dengan model pembelajaran kreatif-kritis ini siswa juga lebih mudah memahami materi pembelajaran karena pokok permasalahan yang dikaji didasarkan pada masalah-masalah aktual yang dihadapi masyarakat terutama dalam kaitannya dengan masalah pendidikan masyarakat, serta memudahkan mahasiswa dalam mencoba untuk merumuskan berbagai alternatif pemecahan masalah sesuai kemampuan masing-masing. Dari hasil penelusuran angket tentang respon mahasiswa terhadap model pembelajaran kreatif-kritis ini, ternyata dari 75 orang siswa yang menyatakan rasa puas dan sangat puas terdapat 53 orang $(86,36 \%)$ dan selebihnya menyatakan cukup puas yaitu 12 orang (13,64\%). Ternyata mereka yang hanya menyatakan cukup puas saja, setelah dilihat dari daftar kehadiran serta aktifitas dalam kelompok termasuk yang tingkat kehadiran dan aktifitasnya kurang dari 90\%, dan juga mengalami keterlambatan mengumpulkan tugas yang tidak sesuai jadwal sebanyak 7 orang $(9,09 \%)$. Mereka yang terlambat mengumpulkan tugas tersebut memberikan alasan yang berbeda-beda, yaitu ada yang dapat dikategorikan sebagai alasan yang masuk akal secara akademis (misalnya kurang memiliki materi bahan ajar dan buku mengenai perkembangan Budaya Pandhalungan di Jember), dan ada pula yang beralasan bersifat subyektif individual (seperti sakit, ada keperluan keluarga dll). Dari 7 orang siswa yang tingkat keaktifannya kurang tersebut terdapat 4 orang yang memiliki nilai baik dan 2 orang siswa memiliki nilai masih kurang baik. ${ }^{8}$

Berdasarkan hasil penelitian dapat diketahui bahwa nilai siswa mengalami kenaikan ditunjukkan dengan rerata nilai hasil belajar ketika pembelajaran dilakukan observasi, studi pustaka, penugasan lapangan dan perumusan alternative pemecahan masalah-masalah aktual dimana nilai rerata mengalami kennaikan dari siklus I ke siklus II yaitu dari nilai rerata sebesar 67,66 menjadi 79,11. Peningkatan nilai hasil belajar ini dapat dikatakan bahwa prestasi belajar meningkat setelah melakukan kegiatan pada siklus II yaitu dengan menerapkan keenam domain kognitif (sebagaimana teorinya Bloom), yaitu domain knowledge, comprehension, application, analysis, sintesis, dan evaluatin, serta menerapkan perpaduan strategi atau metode: lectur, modularized instruction, programmed instruction, discussion, simulation and games, CAL, mudularized instruction, field experience, laboratory, independent/group project, simulation, role playing, laboratory. Peningkatan prestasi belajar siswa diperoleh ketika kegiatan berubah menjadi tidak lagi sekedar menerima informasi (konvensional), tetapi lebih menekankan pada praktik lapangan untuk menemukan permasalahan aktual serta merumuskan alternatif pemecahannya. Kegiatan praktik analisis data dan mencari data di lapangan dimaksudkan agar kemampuan siswa untuk berfikir kreatif-kritis dapat meningkat. Praktik yang dilakukan berupa praktik analisis data dimana data yang dianalisis merupakan data simulasi yang sudah disiapkan oleh guru (peneliti). Kegiatan

\footnotetext{
${ }^{8}$ Hasil angket Sosiologi terhadap 75 siswa disertai wawancara secara random untuk mengetahui tingkat keberhasilan siswa dengan pendekatan model kreatif-kritis.
} 
praktik analisis data ini kemudian dilengkapi dengan kegiatan mencari data di lapangan yang menjadikan siswa memiliki pengalaman bagaimana memperoleh data. Praktik analisis data simulasi dan data riil terbukti membuat mahasiswa tidak hanya mampu memahami konsep materi yang dipelajari dalam mata kuliah sosiologi pendidikan, akan tetapi membantu siswa menafsirkan hasil analisis data dengan bantuan kegiatan di masyarakat. ${ }^{9}$

Dengan demikian dapat dikatakan bahwa respon peserta didik terhadap pembelajaran kreatif-kritis cenderung lebih positif dibanding dengan pembelajaran konvensional atau hanya dilakukan di kelas saja, dan kegiatan implementasi model pembelajaran untuk meningkatkan kemampuan berfikir kreatif-kritis terbukti dapat meningkatkan prestasi kelas XII IPS di SMAN 3 Jember terkait materi perubahan social dan struktur fungsionalisme dalam Budaya Pandhalungan sebagai Cultural Heritage Masyarakat Jember. Berdasarkan hasil pengamatan dari penugasan siswa yang diantaranya terlibat aktif dalam kegiatan masyarakat menyatakan bahwa keadaan masyarakat Jember yang heterogen juga memiliki pengaruh kuat terhadap kehidupan sosial budaya siswa di lingkungan sekitar, sehingga banyak dari mereka yang terkadap berbahasa Jawa atau Madura berdialek Jember. Budaya pandhalungan yang mencakup topeng Madura masih dilaksanakan untuk mengobati kerinduan etnis Madura akan tempat tinggalnya, tarian Ta'Butaan yang masih dilaksanakan dalam acara tahunan bersih desa di Kamal, macan kaduk di daerah Kalisat, dan lain sebagainya yang dapat mendukung keterwujudan penanaman nilai-nilai budaya Pandhalungan di kalangan siswa. Pengaruh yang paling dominan adalah siswa menjadi kaya akan pengetahuan akan eksistensi budaya Pandhalungan melalui pembelajaran sosiologi di sekolah, maupun pandhalungan di sekitar masyarakat. Dari sinilah kearifan lokal masyarakat Jember akan diapresiasi tinggi oleh generasi muda.

\section{KESIMPULAN}

Pembelajaran sosiologi merupakan pembelajaran penting yang tidak dipisahkan dari kearifan lokal bangsa Indonesia, karena sejarah sebagai pembentuk karakter kebangsaan. Tujuan pendidikan dalam kurikulum 2013 berpihak pada penekanan aspek moralitas, cinta kebangsaan, dan kearifan lokal, sehingga sangat dibenarkan bila budaya Pandhalungan dapat berperan sebagai bagian dari multietnis hasil budaya masyarakat Jember. Masyarakat Pandalungan di wilayah tapal kuda adalah masyarakat hibrida yang merupakan perpaduan dari 2 budaya dominan, yakni budaya Jawa dan budaya Madura. Orang pandalungan sangat adaptif dan akomodatif sehingga perubahan-perubahan besar yang melanda dunia ditangkap dengan mudah dan bahkan ditiru. Meski pengaruh Islam sangat kuat, orang pandalungan sangat terbuka dan selalu dinamis tanpa menenggelamkan budaya lokal yang sudah ada. Budaya Pandhalungan di wilayah Jember sebagai hasil multikultural dua etnis mayoritas, Jawa dan Madura, yang melakukan komunikasi aktif terhadap etnis-etnis lain. Migrasi besar-besaran yang terjadi sejak penjajahan Belanda turut berpengaruh terhadap pembentukan budaya

\footnotetext{
${ }^{9}$ Hasil pengamatan siswa dalam kelompok-kelompok kecil yang ditugaskan di desa Ajung dan sekitar lingkungan rumah untuk mengamati dan turut serta dalam kegiatan masyarakat selama lebih dari 14 hari sejak awal bulan Agustus 2017
} 
Pandhalungan yang berkembang di masa kekinian. Selain sebagai cultural heritage, budaya Pandhalungan adalah bagian dari perubahan social dan pengamatan generasi muda dalam memperkuat pertahanan identitas kebangsaan dan mempertahankan eksistensitas Negara Kesatuan Republik Indonesia. Di dalam kelas, penggunaan tema Budaya Pandhalungan dalam pembelajaran sosiologi, terutama penggunaan model belajar kreatif-kritis, mampu meningjatkan prestasi belajar siswa kelas XII IPS SMAN 3 Jember. Hal ini ditunjukkan dengan adanya peningkatan nilai rerata kelas. Nilai kelas yang dibagi dalam tiga kategori menunjukkan peningkatan semua. Atau dapat dikatakan bahwa nilai kuliah kelas, nilai aktivitas diskusi kelompok, nilai penugasan individu dan nilai praktik lapangan meningkat dengan adanya implementasi model pembelajaran kreatif-kritis. Dapat ditarik benang merah bahwa pewarisan nilai-nilai Pandhalungan melalui pembelajaran sosiologi dalam Model Kreatif-Kritis siswa kelas XII IPS SMAN 3 jember berjalan dengan konstruktivis, dikarenakan siswa dapat benar-benar memahami dan menganalisis kebudayaan asli yang dimiliki. Hal ini dapat menjadi potensi bagi kecintaan tanah air generasi muda, sehingga dapat berfokus pada kemajuan bangsa Indonesia.

\section{DAFTAR PUSTAKA}

Ahimsa, H. 1990. "Herritage, Warisan atau Pusaka". Yogyakarta : UGM University Press

Augustinus, A. 2014. De Civitas Dei (Latin). USA : North Charleston

Banda. 2016. Sociological Perpective of The Role of The Teacher in The $21^{\text {st }}$ Century.

Kwame Nkrumah University : International Journal of Humanities Social Science and Education (IJHSSE) Vol 3, Issue 1.

Btubara, M. 2004. Sosiologi Pendidikan. Jakarta : Ciputat Press

Burhan, Edi. 2007. Hibrida Budaya Pandhalungan. Jember: Universitas Jember

Foucault, M. 1989. Education in Sociology : Knowledge, Power, and Critical. Berkeley : University of California Press

Gillin, John Lewis. 1926. "The Development of Sociology in the United States". American Sociological Society, vol XXI

Khaldun, I. 2008. Study of History. USA : University of Maryland

Pieterse, N. 1990. Globalization as Hybridization. Paris : Paris University Press

Poh Swee Hiang. (2000). Kemahiran Berfikir Secara Kritis dan Kreatif. Edisi Kedua. Kuala Lumpur : Kumpulan Budiman Sdn. Bhd

Ruggiero, V (1991). Thinking A Guide to Critical and Creative Thought. New York : Harper Collins Publisher.

Smith, A. 1991. Nation Identity. England : Penguin Books London

Yuswadi, Hary. Masyarakat (Pendalungan) Jember: Pola Hibridisasi Budaya antar Etnis, dalam Jurnal Sosial-Budaya Politik, Vol I. No.1 Nopember. 